Chirurgia (2020) 115: 380-384

No. 3, May - June

Copyright@ Celsius

http://dx.doi.org/10.21614/chirurgia.115.3.380

\title{
Omega Hepatojejunostomy and Hepatic Haemostasis Using the Electrocautery Greased with Lidocaine Gel
}

\author{
Andy Petroianu*, Luiz Ronaldo Alberti, Kelly Renata Sabino \\ Department of Surgery of School of Medicine of the Federal University of Minas Gerais, Brazil
}

*Corresponding author:

Professor Andy Petroianu

Avenida Afonso Pena, 1626 - Apto 1901

Belo Horizonte, MG, 30130-005, Brazil

Phone (Fax): (5531) 98884-9192, 32747744

E-mail: petroian@gmail.com

\section{Rezumat \\ Hepaticojejunostomie în omega și hemostaza hepatică folosind electrocauterul uns cu gel cu lidocaină}

Context: Când întregul pedicul hepatic este invadat de tumoră, tratamentul colestaziei reprezintă o provocare atât pentru a alege cea mai bună posibilitate de drenare, cât şi a modului de a realiza hemostaza hepatică în timpul unei proceduri chirurgicale.

Prezentare de caz: Un pacient cu icter progresiv rezultat dintr-o tumoră gastrică rămasă, care a invadat vezica biliară şi pediculul hepatic, a fost tratat cu succes cu decompresie biliară cu ajutorul unei derivații hepaticojejunale. Sângerarea parenchimatoasă minoră a fost obținută cu electrocauterul uns cu gel cu lidocaină. Ars de electrocauter, gelul cu lidocaină a creat o crustă de etanşare care a recuperat tot parenchimul hepatic. S-a realizat imediat o hemostază eficientă şi stabilă. Pacientul a avut o evolutie post-operatorie fără complicație şi toate manifestările de colestază inclusiv icterul şi pruritul au scăzut încă din prima zi. Pacientul a supraviețuit nouă luni cu icter scăzut asimptomat.

Concluzie: In prezența implicării generale a canalelor biliare, derivația omega hepatojejunală reduce manifestările colestaziei şi îmbunătățeşte calitatea vieții pacientului. Electrocauterul uns cu gel cu lidocaină este o metodă ieftină, uşor disponibilă şi eficientă pentru a realiza hemostaza hepatică imediată.

Cuvinte cheie: hemostază, hepaticojejunostomie, derivație omega, ficat, icter, lidocaină 


\begin{abstract}
Background: When the entire hepatic pedicle is invaded by a tumour, the treatment of cholestasis represents a challenge both for choosing the best drainage possibility and for performing the liver haemostasis during a surgical procedure.

Case report: A patient with progressive jaundice resulting from a remaining gastric tumour that invaded the gallbladder and the hepatic pedicle was successfully treated with biliary decompression using the omega hepaticojejunal shunt. The minor parenchymal bleeding was achieved with the electrocautery greased with lidocaine gel. When burned by the electrocautery, the lidocaine gel made a sealing crust that recovered all the liver parenchyma. Efficacious and stable haemostasis was immediately achieved. The patient had an uneventful early postoperative follow-up, and all cholestasis manifestations, including jaundice and pruritus, decreased since the first day. The patient survived nine months with asymptomatic low jaundice.

Conclusion: In the presence of general involvement of the bile ducts, the omega hepaticojejunal shunt reduces the manifestations of cholestasis and improves the patient's quality of life. The electrocautery greased with lidocaine gel is inexpensive, easily available and efficacious method to achieve immediate hepatic haemostasis.
\end{abstract}

Key words: haemostasis, hepaticojejunostomy, omega shunt, liver, jaundice, lidocaine gel

\section{Introduction}

Biliodigestive shunt procedures using the bile ducts cannot be performed in the presence of tumours that invade the entire hepatic pedicle $(1,2)$. Patients course with severe jaundice, accompanied by incessant and refractory to drug control pruritus, with impairment in hepatocyte function, coagulation disorders and risk of renal failure (1).

In these cases, most services treat patients with external hepatic drainage and, when possible, internal drainage with a prosthesis, via endoscopy. However, in some patients, these procedures are ineffective, and the remained option is the hepaticojejunal shunt, which can be performed with an isolated $\mathrm{Y}$ or omega jejunal loop. This operation requires partial hepatectomy, usually using the left lobe of the liver. One of the challenges of this procedure is the haemostasis in a patient with coagulation disorders, due to the obstructive liver disease, and performing it without occluding the peripheral bile ducts is another difficulty to be solved (3).

\section{Case Report}

A 64-year-old man was referred to our service having a diagnosis of obstructive jaundice due to a large mass in the topography of the pancreas head and invading the whole hepatic hilum. Dilation of the intrahepatic biliary ducts and ascites were identified by computed tomography (CT). His main complaint was jaundice associated with intense and continuous itching, with multiple skin wounds, in addition to other manifestations of the cholestatic syndrome. About eight years earlier, he underwent a radical subtotal gastrectomy and gastrojejunal anastomosis, due to gastric adenocarcinoma, in another service.

At admission, the patient was pale $(2+/ 4+)$, hydrated, jaundiced $(4+/ 4+)$, eupneic, acyanotic and afebrile. The abdomen was enlarged, with signs of ascites, painless on palpation and with peristalsis. Biochemical tests showed direct bilirubin of $14.3 \mathrm{mg} / \mathrm{dl}$, indirect bilirubin of $3.1 \mathrm{mg} / \mathrm{dl}$, amylase of $37 \mathrm{U} / \mathrm{l}$, lipase of $175 \mathrm{U} / \mathrm{l}$, albumin of $2.0 \mathrm{~g} / \mathrm{dl}$, creatinine of $1.6 \mathrm{mg} / \mathrm{dl}$.

The surgical treatment was chosen due to the intense ascites, which contraindicates 
percutaneous biliary drainage. At the laparotomy, massive ascites and a large tumour, which encompassed the head of the pancreas, the gallbladder and the entire hepatic hilum confirmed the CT diagnosis. A tumour biopsy was performed, followed by hepaticojejunal shunt in the left lobe of the liver.

A liver segment measuring $6 \mathrm{~cm}$ in thickness and $13 \mathrm{~cm}$ in length was removed using the electrocautery. The liver resection was conducted with the ligature of major blood vessel, but not the bile ducts. (Fig. 1A) The minor parenchymal bleeding was achieved with the electrocautery greased with lidocaine gel. (Fig. 1B) When burned by the electrocautery, the lidocaine gel made a sealing crust that recovered all the liver parenchyma (Fig. 1O). Efficacious and stable haemostasis was immediately achieved.

A segment of jejunal loop, about $50 \mathrm{~cm}$ from the gastrojejunal anastomosis previously performed, was opened longitudinally to the extent of the hepatic opening. This loop was anastomosed to the liver laterally with continuous suture, using 4-0 PDS thread (Fig. 1D). Then, the proximal and distal loops
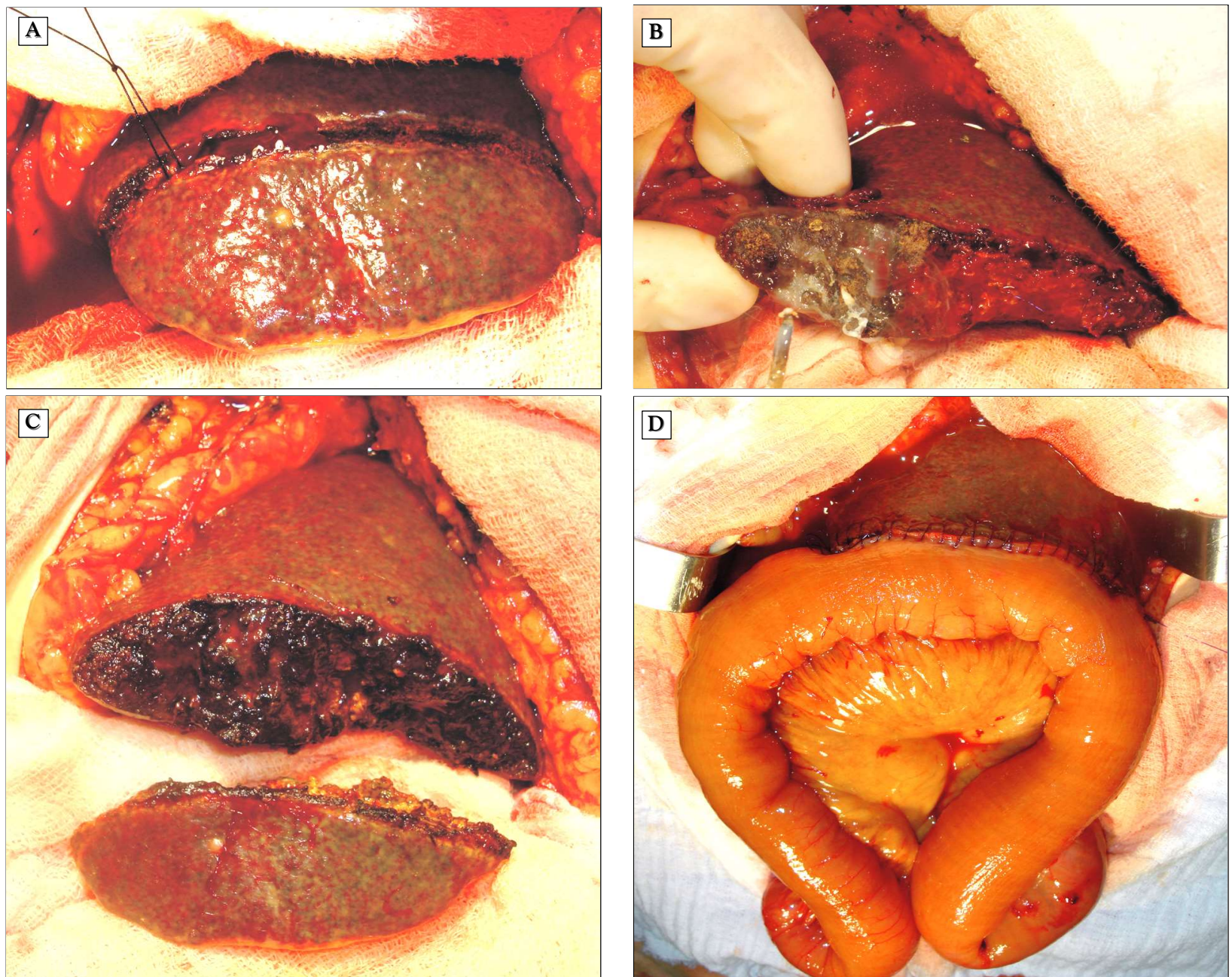

Figure 1. Surgical views of omega hepaticojejunostomy with haemostasis obtained by mean of electrocautery greased with lidocaine gel. (A) Ligature of larger blood vessels during the resection of the liver. (B) Lidocaine gel being administrated by electrocautery on a liver parenchyma surface after segmental liver resection. (C) Final result of the liver parenchyma haemostasis after liver resection. Observe the removed liver segment. (D) Omega hepaticojejunostomy after the hepaticojejunal running suture. 
to this anastomosis were anastomosed laterally with 3-0 PDS thread, forming the omega shunt. The food transit followed through the intestine without passing through the hepaticojejunal shunt.

The patient had an uneventful early postoperative follow-up, and all cholestasis manifestations, including jaundice and pruritus, decreased since the first day. The drained fluid did not indicate haemorrhage, but only light haemorrhagic aspect in the early two days and became clear after the third postoperative day. On the third day, the oral diet was resumed with good acceptance. After the absence of abdominal fluid, the collection was confirmed by ultrasound, the drain was removed, and the patient was discharged in good general condition on the sixth postoperative day. The patient survived nine more months with asymptomatic low jaundice.

The pathological examination of the biopsy revealed gastric adenocarcinoma. Therefore, the tumour was the growth of neoplastic tissue remaining from the previous gastrectomy. The patient was treated with chemotherapy.

\section{Discussion}

Hepatic bile decompression methods had great progress since the end of the $19^{\text {th }}$ century, when Roux, based on the suggestion of his professor, Wolfler, made the first Y-biliary drainage into the jejunum. In 1955, Soupault and Caroli described the hepato-cholangio-jejunostomy for malignant neoplasms (1). Another alternative is the hepaticojejunal anastomosis with an isolated Y loop anastomosed to the left liver, after resection of a distal hepatic segment, proposed by Longmire and Stanford in 1948 $(4,5)$. Subsequently, the hepaticojejunal shunt was made with other parts of the liver and with Y or omega loops. Lasala's hepato-cholecystojejunostomy is another palliative possibility by draining the liver parenchyma through the gallbladder into a jejunal $\mathrm{Y}$ loop. These procedures are recommended for high biliary obstructions when there is no access to the bile ducts $(1,2,4,5)$.

The hepaticojejunostomy must prevent the food reflux into the bile ducts due to the risk of cholangitis. In this sense, the jejunal loop of the Roux-en-Y, must have at least 40 centimetres. After performing an omega shunt, the food reflux into the bile ducts through the hepaticojejunal anastomosis is prevented by a jejunojejunostomy between the proximal and distal portions of the jejunum $(1,5,6)$. These palliative shunts improve the quality of life of patients with cholestasis, and increase their survival, by preventing complications such as cholangitis, as well as hepatic and renal failures.

Percutaneous drainage would have been less aggressive; however, in the presence of ascites, no percutaneous liver procedure should be performed. The peritoneal fluid prevents the blockage of liver bleeding and biliary leak leading to life-threatening hemoand choleperitoneum. Besides that, in favourable conditions, percutaneous drainage is followed by an average survival of three months, even with adjuvant chemotherapy $(6,7)$. Otherwise, after hepaticojejunostomy, the average survival is of eight months $(4,6)$.

The hepatic haemostasis used in the patient mentioned in this report was based on the crust of coated ointment, which sealed all minor vessels and stopped the bleeding without occluding the bile ducts. The coagulant from the lidocaine was the coated crust since no lidocaine component gel is recognized as a coagulant (3). Other devices, such as cauterization with radiofrequency, ultrasound, or LASER improved the results of haemostasis. Vascular sealing with fibrin and collagen ointment is also an effective method of stopping the bleeding (8-10). However, all these haemostatic methods are expensive and not available in all surgical centres. The electrocautery greased with lidocaine is an inexpensive and available procedure; it is useful to stop minor bleedings of liver, spleen and bone in open and laparoscopic surgical procedures.

\section{Conclusion}

In the presence of extensive involvement of 
the bile ducts, the omega hepaticojejunal shunt reduces the manifestations of cholestasis and improves the patient's quality of life. The electrocautery greased with lidocaine gel is inexpensive, easily available and efficacious method to achieve immediate hepatic haemostasis.

\section{Conflict of Interests}

The authors declare no conflict of interest related to this case report and its publication.

\section{References}

1. Hepp J, Couinaud C. L'abord et utilization du canal hépatique gauche dans les reparetion de la voie biliare principale. Presse Méd, 1956; 64(41): 947-8.

2. Mangieri CW, Strode MA, Bandera BC. Improved hemostasis with major hepatic resection in the current surgical era. Hepatobiliary Pancreat Dis Int. 2019,18(5):439-45

3. Petroianu A. Hemostasis of the liver, spleen and bone achieved by electrocautery greased with lidocaine gel. Surg. Today 2011;41: 300-2.

4. Sastry A, Sulzer JK, Passeri M, Baker EH, Vrochides D, McKillop IH, et al. Efficacy of a Laparoscopic Saline-Coupled Bipolar Sealer in Minimally Invasive Hepatobiliary Surgery. Surg Innov. 2019, 26(6): 668-74.

5. Bismuth $\mathrm{H}$, Castaing $\mathrm{D}$, Traynor 0 . Resection or palliation: priority of treatment of hilar cancer. World J Surg. 1988;12:39-47.

6. Levy JL, Sudheendra D, Dagli M, Mondschein JI, Stavropoulos SW, Shlansky-Goldberg RD, et al. Percutaneous biliary drainage effectively lowers serum bilirubin to permit chemotherapy treatment. Abdom Radiol. 2016:41:317-23

7. Sutter CM, Ryu RK. Percutaneous Management of Malignant Biliary Obstruction. Tech Vasc Interv Radiol. 2015;18:218-26.

8. Weber JC, Navarra G, Jiao LR. New technique for liver resection using heat coagulative necrosis. Ann Surg. 2002;236:560-3.

9. Schwartz M, Madariaga J, Hirose R. Comparison of a new fibrin sealant with standard topical hemostatic agents. Arch Surg. 2004; 139:1148-54.

10. Jiao LR, Navarra G, Weber JC. Radiofrequency assisted liver resection. Hepatogastroenterology. 2005;52:1685-7. 